\title{
Effect of age on semen parameters in infertile men after varicocelectomy
}

This article was published in the following Dove Press journal:

Therapeutics and Clinical Risk Management

8 August 201I

Number of times this article has been viewed

\section{Kamaleddin \\ Hassanzadeh-Nokashty' \\ Parisa Yavarikia ${ }^{2}$ \\ Alireza Ghaffari ${ }^{3}$ \\ Samad Hazhir ${ }^{\prime}$ \\ Mohammadali Hassanzadeh' \\ 'Department of Urology, ${ }^{2}$ Faculty of Nursery and Midwifery, ${ }^{3}$ Department of Internal Medicine, Tabriz University of Medical Sciences, Tabriz, Iran}

Correspondence: Kamaleddin Hassanzadeh-Nokashty Department of Urology, Tabriz University of Medical Sciences,

Tabriz, Iran

Tel $+984 \mid \quad 1477 \quad 622$

Fax +98 4I I477 I622

Email drhassanzadehka@yahoo.com
Background: The effectiveness of varicocelectomy in restoration of fertility and improvement of semen parameters is still controversial. The purpose of this study was to determine the effect of age on semen parameters following varicocelectomy in a group of infertile men.

Methods: Improvements in sperm count, morphology, and motility were studied in 67 infertile patients 4-10 months after varicocelectomy.

Results: The mean age of the patients was $30.48 \pm 7.49$ years. Significant improvements in total sperm count, percentage normal morphology, and motility were noted in all age groups $(P<0.05)$. Patients aged $<25$ years demonstrated the greatest increase in sperm counts, normal morphology, and motility following varicocelectomy. There was a significant negative correlation between age and sperm count, sperm morphology, and sperm motility $(P<0.05)$.

Conclusion: The effect of age on improvement in sperm parameters after varicocelectomy is inconsistent with some reports in the literature, and could be attributable to the duration of infertility prior to surgery; in the long term, varicoceles are known to have deleterious effects on testis biology.

Keywords: sperm count, sperm morphology, sperm motility, varicocele

\section{Introduction}

Varicocele, a bilateral vascular disease in which hypoxia can lead to ischemic damage to both testes due to hydrostatic pressures in the impaired venous drainage system, is a major cause of male infertility, ${ }^{1}$ the pathophysiology of which is multifactorial. ${ }^{2}$ Numerous studies have targeted the issue of varicocele-associated infertility. ${ }^{3,4}$ The belief that it is not linked to male infertility is based on reviews of prospective randomized studies in which varicocele repair was concluded to be an ineffective treatment for male subfertility ${ }^{5,6}$ and research demonstrating no significant improvement in semen parameters, sperm morphology, or motility following ligation of the testicular veins in infertile couples in which the male partner presented with varicocele. ${ }^{7}$ However, surgical correction of varicocele by varicocelectomy was reported to cause a 70\% improvement in semen quality in 986 subfertile men, and a preoperative sperm count $>10$ million per $\mathrm{mL}$ was associated with a better outcome. ${ }^{8}$ Fode et al suggested that an association between varicocele and male infertility is likely, ${ }^{9}$ and Gat et al concluded that the conflict arises because the vast majority of patients are only partially treated on the left side. ${ }^{1}$ There is evidence that sperm DNA fragmentation is reduced and the pregnancy rate increased after surgery, ${ }^{10}$ and that bilateral surgery, even when varicocele is subclinical in one testis, effects more improvement than unilateral surgery. ${ }^{11}$ 
A few studies of varicocele and its treatment have investigated the effect of patient age on the outcome. One report concluded that patient age does not affect the outcome, ${ }^{12}$ and while there is no clear evidence of improvement in older men, it has been suggested that varicocele repair is associated with improved seminal parameters and improved fertility in young adults. ${ }^{13}$ In view of the many conflicting reports concerning the efficacy of varicocelectomy in the restoration of fertility and improvement of semen parameters, this study was carried out to determine the effect of age on semen parameters following varicocelectomy in a group of infertile men.

\section{Methods}

In a prospective study, 67 patients presenting with grade III varicocele and infertility, who underwent unilateral left inguinal varicocelectomy during a 1 -year period, were enrolled. Inclusion criteria were age 20-50 years, grade III varicocele, and oligoasthenospermia. Abnormality in semen analysis parameters was defined according to the World Health Organization (WHO) criteria. ${ }^{14}$ Patients with azoospermia, bilateral varicocele, underlying diseases such as hyperthyroidism, hypothyroidism, or diabetes mellitus, and a drug history of gonadotropin and/or testosterone were excluded from the study. All the patients studied were within the normal range regarding hormonal status and testicular volume. The diagnosis and grading of varicocele was made clinically. ${ }^{15}$ Informed consent was obtained prior to an individual being included in the study. ${ }^{16}$ Semen samples were obtained by masturbation during their visit to the Department of Urology, Sina Hospital, Tabriz, Iran. We followed the method for sperm counting by hemacytometer recommended by the WHO. ${ }^{14}$ Sperm analyses (count, morphology, and motility) were carried out according to WHO criteria. Patients were followed up for 4-10 (mean 6) months following varicocelectomy and sperm analyses were repeated. In order to assess the effect of age on improvement in sperm parameters after varicocelectomy, the patients were divided into four age groups, ie, $<25$ years $(\mathrm{n}=17), 25-29$ years $(\mathrm{n}=18), 30-34$ years $(\mathrm{n}=17)$, and $>35$ years $(\mathrm{n}=15)$.

\section{Statistical analysis}

Data are presented as means \pm standard deviation (SD) or percentages. Statistical analysis was performed with SPSS for Windows (v 12.0; SPSS Inc, Chicago, IL) and using one-way analysis of variance with the Tukey's post hoc test, KruskalWallis test, and Mann-Whitney U test, whenever appropriate. Spearman's correlation coefficient was calculated to study the correlation between sperm characteristics and age groups. A $P<0.05$ was considered statistically significant.

\section{Results}

The mean age of the patients was $30.48 \pm 7.49$ years. There was no significant difference in sperm analysis parameters among the age groups at the baseline $(P>0.05)$. Significant improvements in total sperm count, percentage normal morphology, and motility were noted in all age groups $(P<0.05)$. Patients in the first age group, ie, those aged $<25$ years, demonstrated the greatest increase in the sperm count, normal morphology, and motility following varicocelectomy (Table 1). There was a significant negative correlation between age and sperm count $(r=-0.51$, $P=0.01)$, sperm morphology $(r=-0.47, P=0.04)$, and sperm motility $(r=-0.42, P=0.02)$.

\section{Discussion}

Varicocelectomy has been reported to improve the semen profile significantly in the majority of patients, and to result in a slight decrease in the frequency of aneuploidy in some chromosomes. ${ }^{17}$ In the present study, varicocelectomy improved the semen profile of all participants in terms of sperm count, morphology, and motility. However, there are reported cases in which varicocelectomy appears to cause infertility, possibly due to compromised blood flow

Table I Characteristics of sperm analysis before and after varicocelectomy in different age groups

\begin{tabular}{|c|c|c|c|c|c|c|}
\hline & & \multicolumn{4}{|l|}{ Age groups } & \multirow[t]{2}{*}{$P$ value } \\
\hline & & $\begin{array}{l}<25 \text { years } \\
(n=17)\end{array}$ & $\begin{array}{l}25-29 \text { years } \\
(n=18)\end{array}$ & $\begin{array}{l}30-34 \text { years } \\
(n=17)\end{array}$ & $\begin{array}{l}\geq 35 \text { years } \\
(n=15)\end{array}$ & \\
\hline \multirow[t]{2}{*}{ Sperm count } & Before & $31.76 \pm 3.15$ & $32.95 \pm 4.52$ & $27.05 \pm 6.24$ & $25.30 \pm 5.78$ & \multirow[t]{2}{*}{$<0.001$} \\
\hline & After & $56.17 \pm 10.29$ & $52.50 \pm 8.67$ & $42.92 \pm 7.11$ & $37.00 \pm 10.58$ & \\
\hline Sperm normal & Before & $28.23 \pm 12.37$ & $30.83 \pm 9.25$ & $28.08 \pm 10.85$ & $27.36 \pm 11.02$ & \multirow[t]{2}{*}{0.03} \\
\hline morphology (\%) & After & $46.47 \pm 15.25$ & $44.16 \pm 13.42$ & $40.38 \pm 11.36$ & $37.20 \pm 14.25$ & \\
\hline \multirow[t]{2}{*}{ Sperm motility (\%) } & Before & $26.17 \pm 10.85$ & $28.05 \pm 13.73$ & $29.15 \pm 15.02$ & $25.56 \pm 8.59$ & \multirow[t]{2}{*}{0.01} \\
\hline & After & $55.29 \pm 16.91$ & $52.77 \pm 19.15$ & $48.84 \pm 13.59$ & $40.50 \pm 14.25$ & \\
\hline
\end{tabular}


through the testicular artery ${ }^{18}$ or dysregulated apoptosis of the internal spermatic vein, indicated by changes in Bcl-2 and caspase 9 levels that persist after surgery. ${ }^{19}$ Such cases should preclude the use of unilateral varicocelectomy to correct infertility problems. ${ }^{9}$

Evidence suggests that varicocele has a deleterious effect on testicular biology over time, ${ }^{20}$ and therefore successful treatment using varicocelectomy is more likely if the period of infertility preceding surgery is short. Early repair, especially if the varicocele is large, appears to be beneficial for subsequent fertility and in terms of androgen levels. ${ }^{21}$ In this study, those individuals aged $<25$ years demonstrated the greatest improvement in all semen parameters studied. This finding is in contrast with that of previous studies showing insignificant changes in semen parameters after varicocele repair in different age groups. Ishikawa and Fujisawa indicated that even in men older than 40 years of age, sperm concentration and motility increased significantly after varicocele ligation. ${ }^{22}$ In addition, Zini et al found similar sperm parameters and spontaneous pregnancy rates following varicocelectomy in couples with advanced paternal age ( $\geq 40$ years) compared with younger couples. ${ }^{23}$ Recently, Reşorlu et $\mathrm{al}^{12}$ and Liguori et $\mathrm{al}^{24}$ reported no significant alterations in sperm concentration and motility rates after ligation between the different age groups. In contrast, Rodriguez Peña et al concluded that varicocele repair was associated with improved seminal parameters and improved fertility in young adults. ${ }^{13}$

This study has certain limitations. We did not include patients with bilateral varicocele due to different grades of this disease on both sides. Furthermore, possible confounding factors such as follicle-stimulating hormone, testosterone, and testicular volume, were controlled over the study period; all the studied patients were within the normal range regarding hormonal status and testicular volume. However, no exact details of these parameters were available to be reported. In addition, no assessment of DNA damage was performed in the present study. Moreover, due to its short follow-up duration, no thorough survey was performed of pregnancies achieved during the study period, naturally or with assisted reproductive technologies.

In conclusion, improvement in semen parameters after varicocelectomy was more marked in the youngest patients ( $<25$ years) than in the older groups. This effect could be attributable to the length of the period of infertility prior to surgery. In the long term, varicoceles are known to have deleterious effects on testis biology. This might give further credence to the concept that early intervention is more likely to be successful, and that age may have an effect on the efficiency of varicocelectomy as a treatment for male infertility.

\section{Disclosure}

The authors report no conflicts of interest in this work.

\section{References}

1. Gat Y, Zukerman Z, Chakraborty J, Gornish M. Varicocele, hypoxia and male infertility. Fluid mechanics analysis of the impaired testicular venous drainage system. Hum Reprod. 2005;20:2614-2619.

2. Ghabili K, Shoja MM, Agutter PS, Agarwal A. Hypothesis: intracellular acidification contributes to infertility in varicocele. Fertil Steril. 2009; 92:399-401.

3. Fang Y, Zhao L, Yan F, Xia X, Xu D, Cui X. Escin improves sperm quality in male patients with varicocele-associated infertility. Phytomedicine. 2010;17:192-196.

4. Lacerda JI, Del Giudice PT, da Silva BF, et al. Adolescent varicocele: improved sperm function after varicocelectomy. Fertil Steril. 2011; 95:994-999.

5. Evers J, Collins A. Assessment of efficacy of varicocele repair for male subfertility: a systemic review. Lancet. 2003;361:1849-1852.

6. Evers JL, Collins JA. Surgery or embolization for varicocele in subfertile men. Cochrane Database Syst Rev. 2004;3:CD000479.

7. Nilsson S, Edvinsson A, Nilsson B. Improvement of semen and pregnancy rate after ligation and division of the internal spermatic vein: fact or fiction? Br J Urol. 1979;51:591-596.

8. Dubin L, Amelar RD. Varicocelectomy: 986 cases in a twelve-year study. Urology. 1977;10:446-449.

9. Fode M, Sønksen J. Varicoceles. Ugeskr Laeger. 2009;171:3424-3429.

10. Smit M, Romijn JC, Wildhagen MF, Veldhoven JL, Weber RF, Dohle GR. Decreased sperm DNA fragmentation after surgical varicocelectomy is associated with increased pregnancy rate. $J$ Urol. 2010;183:270-274.

11. Elbendary MA, Elbadry AM. Right subclinical varicocele: how to manage in infertile patients with clinical left varicocele? Fertil Steril. 2009;92:2050-2053.

12. Reşorlu B, Kara C, Sahin E, Unsal A. The significance of age on success of surgery for patients with varicocele. Int Urol Nephrol. 2010;42: 351-356.

13. Rodriguez Peña M, Alescio L, Russell A, Lourenco da Cunha J, Alzu G, Bardoneschi E. Predictors of improved seminal parameters and fertility after varicocele repair in young adults. Andrologia. 2009;41:277-281

14. World Health Organization. Laboratory manual for the examination of human semen and sperm-cervical mucus interaction. 4th ed. Cambridge, UK: Cambridge University Press; 1999.

15. Peter NS, Matthew PH, Marc G. Male reproduction physiology. In: Wein AJ, Kavoussi LR, Novick AC, Partin AW, Peters CA, editors. Campbell-Walsh urology. 9th ed. Philadelphia, PA: Saunders; 2007.

16. Khoshbaten M, Naderpour M, Mohammadi G, Alipoor SH, Estakhri R, Fazeli Z. Epidemiology of esophageal lesions in patients with head and neck squamous cell carcinoma. Asian Pac J Cancer Prev. 2010; $11: 863-865$.

17. Acar H, Kilinc M, Guven S, Yurdakul T, Celik R. Comparison of semen profile and frequency of chromosome aneuploidies in sperm nuclei of patients with varicocele before and after varicocelectomy. Andrologia. 2009;41:157-162.

18. Salem HK, Mostafa T. Preserved testicular artery at varicocele repair. Andrologia. 2009;41:241-245.

19. Lee JD, Lu LY, Cheng WH, Jeng SY. Dysregulated apoptosis through the intrinsic pathway in the internal spermatic vein of patients with varicocele. J Formos Med Assoc. 2009;108:612-618. 
20. Zorba UO, Sanli OM, Tezer M, Erdemir F, Shavakhabov S, Kadioglu A. Effect of infertility duration on postvaricocelectomy sperm counts and pregnancy rates. Urology. 2009;73:767-771.

21. Kim HH, Goldstein M. Adult varicocele. Curr Opin Urol. 2008;18: 608-612.

22. Ishikawa T, Fujisawa M. Effect of age and grade on surgery for patients with varicocele. Urology. 2005;65:768-772.
23. Zini A, Boman J, Jarvi K, Baazeem A. Varicocelectomy for infertile couples with advanced paternal age. Urology. 2008;72:109-113.

24. Liguori G, Ollandini G, Pomara G, et al. Role of renospermatic basal reflow and age on semen quality improvement after sclerotization of varicocele. Urology. 2010;75:1074-1078.

\section{Publish your work in this journal}

Therapeutics and Clinical Risk Management is an international, peerreviewed journal of clinical therapeutics and risk management, focusing on concise rapid reporting of clinical studies in all therapeutic areas, outcomes, safety, and programs for the effective, safe, and sustained use of medicines. This journal is indexed on PubMed Central, CAS,
EMBase, Scopus and the Elsevier Bibliographic databases. The manuscript management system is completely online and includes a very quick and fair peer-review system, which is all easy to use. Visit http://www.dovepress.com/testimonials.php to read real quotes from published authors.

Submit your manuscript here: http://www.dovepress.com/therapeutics-and-clinical-risk-management-journal 